\author{
Marquette University \\ e-Publications@Marquette
}

College of Education Faculty Research and

Publications

Education, College of

$1-2002$

\title{
Women High School Principals: Perspectives on Role Conflict, Role Commitment, and Job Satisfaction
}

\author{
Ellen Eckman \\ Marquette University, ellen.eckman@marquette.edu
}

Follow this and additional works at: https://epublications.marquette.edu/edu_fac

Part of the Education Commons

\section{Recommended Citation}

Eckman, Ellen, "Women High School Principals: Perspectives on Role Conflict, Role Commitment, and Job Satisfaction" (2002). College of Education Faculty Research and Publications. 119.

https://epublications.marquette.edu/edu_fac/119 


\title{
Women High School Principals: Perspectives on Role Conflict, Role Commitment, and Job Satisfaction
}

\author{
Ellen Wexler Eckman \\ School of Education, Educational Policy and Leadership, \\ Marquette University \\ Milwaukee, WI
}

This study is an investigation of women high school principals in terms of the challenges they face, role conflicts they experience, their role commitment, and their job satisfaction. The purpose is to describe women high school principals addressing the issue of the continued underrepresentation of women in the high school principalship. Quantitative and qualitative data were collected from women high school principals in Illinois, Minnesota, and Wisconsin. The findings indicate that role conflict impacts career decisions-respondents delayed entering the high school principalship until the demands of raising their children had lessened. Role conflict is inversely related to job satisfaction; the more role conflict, the lower the level of job satisfaction. The number of students in the school affects job satisfaction and role conflict. Women today may have more career mobility than in the past. Encouragement and mentoring are key factors in enabling women to become high school principals. 
The disproportionately low representation of women in the public high school principalship is a problem that has persisted over time (Bell \& Chase, 1993; Mertz \& McNeely, 1990; Porat, 1985; Schneider, 1986). The low representation of women in the public high school principalship was demonstrated in this study of public high schools in Illinois, Minnesota, and Wisconsin that was conducted in 1998-1999. Approximately $48 \%$ of high school teachers in these three states are female, yet only $15.2 \%$ of high school principals in these states are female (see Table 1 ). These data indicate that the underrepresentation of women in the public high school principalship continues to be a problem.

This study examines the experiences of female public high school principals to determine the impact of role conflict, role commitment, and job satisfaction on women in the high school principalship. It would be useful for women educators to understand the influence of role conflict, role commitment, and job satisfaction on women high school principals in order to make a thoughtful decision regarding the high school principalship as a career choice. By describing the women who are high school principals, in terms of age, ethnicity, marital status, and the presence of children at home, this study also provides important demographic information. A'S one of the participants in the study commented:

[T]o encourage more women to pursue the principalship, we need to put the whole gender issue more clearly on the table and work with women in terms of the differences that exist, and help them better understand what they're going to face ahead of time.

\section{Literature Review}

Theories about educational administrative behavior have primarily been based on studies of men in organizations with the findings then generalized to women (Valentine, 1995). Historically, this was considered an adequate approach for understanding administrative behavior because few women held positions in educational administration. In the 1980s feminist scholars questioned the underrepresentation of women in administrative positions in education and called for theory and research that would be more

Journal of School Leadership, Vol. 12, No. 1 (January 2002): pg. 57-77. Publisher Link. This article is (C Rowman \& Littlefield and permission has been granted for this version to appear in e-Publications@Marquette. Rowman \& Littlefield does not grant permission for this article to be further copied/distributed or hosted elsewhere without the express permission from Rowman \& Littlefield. 
inclusive of women's perspectives (Edson, 1988; Schmuck, 1981; Shakeshaft, 1989). By the 19908 Marshall and Anderson (1995) argued that women remained underrepresented in educational administrative positions, such as high school principal and superintendent, because increasing the number of women in those positions relied on men in positions of power to create access for women in ways that would have resulted in the loss of positions of power for men. Researchers have had difficulty finding uniform and reliable information on the number of women in educational administration (Bell \& Chase, 1993; Mertz, 1991). Mertz (1991) reported that there were no systematic historical or current data on a national or regional basis that traced the number of females in educational administration over time. Data did not uniformly differentiate the various line positions, such as principal and assistant principal, by the school levels of elementary, junior high, and senior high.

Likewise, some researchers have not distinguished between women in central office positions and women in the positions of elementary, middle, or high school principal and as a result examined all female educational administrators as a group (Edson, 1988; Shakeshaft, 1989). Other researchers focused on women principals, regardless of the type of school (Schmuck \& Schubert, 1995). When women high school principals were studied, they were often included in a group with women superintendents and assistant superintendents (Matthews, 1995; Paddock, 1981). More recently, some researchers have concentrated their studies entirely on women superintendents without examining women high school principals (Bell \& Chase, 1993; Blount, 1998; Brunner, 1997; Grogan, 1996; Pavan, 1999; Scherr, 1995).

A few studies have specifically focused on women high school principals (Fansher \& Buxton, 1984; Mertz \& McNeely, 1988, 1994; Nogay \& Beebe, 1997; Paddock, 1981). These studies provided limited data on the number of women high school principals, their ages, race, marital status, and the location of their high schools. For some studies, the small number of women high school principals meant there were limited data to analyze (Mertz \& McNeely, 1988; Paddock, 1981). In her national study of women in educational administration, Paddock 
(1981) received responses from 97 of the 284 women high school principals (34.2\%). Because of the limited number of female high school principals, Paddock combined the data from the women high school principals with the data from the women assistant superintendents and superintendents in reporting on several variables in her study.

Most of the research about role conflict, role commitment, and job satisfaction has concentrated on women educational administrators as a group, without specifically focusing on women in the high school principalship. Several researchers have documented the existence of role conflict for women in educational administration as they attempt to balance home and family responsibilities with their professional roles (Edson, 1988; Erickson, 1985; Goeller, 1995; Kochan, Spencer, \& Mathews, 2000; Paven, 1991, 1999; Shakeshaft, 1989). Only a few studies, however, have focused specifically on role conflict experienced by women high school principals. In her research on women high school principals, Paddock (1981) found that "the divided role of professional and homemaker is one of the biggest barriers to women's career development" (p. 191). The role conflicts created by the time demands of the secondary school principalship were found to discourage women in their pursuit of the high school principalship (Alley \& McDonald, 1997; Ortiz, 1982; Pounder, 1990). Some researchers noted that women high school principals experienced role conflict because they did not fix the masculine image associated with the role of high school principal (Pigford \& Tonnsen, 1993; Pounder, 1990, 1994). Finally, as Marshall and Kasten (1994) point out, the norms for educational administrators, which require attending numerous evening events and 60-hour workweeks, were "developed around the life cycles of men and outdated assumptions about men's and women's roles in the family and in society" (p. 4).

Role commitment has been described in terms of the costs associated for women when they are forced to choose between their home and families and their careers (Hoschshild, 1989). Napholz (1995b) defined role commitment as the "subjective response on how one sets priorities for work and relationship roles" (p. 24). In her study of working women, the women who chose either work first or significant relationships first had a lower level of role conflict than did

Journal of School Leadership, Vol. 12, No. 1 (January 2002): pg. 57-77. Publisher Link. This article is (C Rowman \& Littlefield and permission has been granted for this version to appear in e-Publications@Marquette. Rowman \& Littlefield does not grant permission for this article to be further copied/distributed or hosted elsewhere without the express permission from Rowman \& Littlefield. 
women who felt a need to commit equally to both work and relationships. Other researchers, in their studies on women in educational administration, have examined the concept of role commitment (Kelly, 1997; Pavan, 1991, 1999). However, to date, there have been no studies that focused exclusively on women high school principals and role commitment.

Women in educational administration have also been studied with regard to their level of job satisfaction. Some researchers found that women in educational administration expressed a high degree of job satisfaction and viewed themselves as effective in their jobs (Cochran, 1979; McCarthy \& Zent, 1981). There have been a few studies where the job satisfaction of women high school principals was specifically researched. Paddock (1981) reported that $80 \%$ of the women high school principals in her study were satisfied and would choose the same career again. Fansher and Buxton (1984) studied 266 women in the secondary school principalship nationwide, focusing on determinants of job satisfaction. They reported that the larger the school enrollment, the older the principal, and the more positive the feedback from the students, the higher the job satisfaction of female high school principals. Unfortunately, other studies of school administrators have neither differentiated by gender nor by school level in their discussions of job satisfaction for principals (Bacharach \& Mitchell, 1983; Bogotch \& Riedlinger, 1993; Gunn \& Holdaway, 1986; Rogus, Poppenhagen, \& Mingus, 1980).

\section{Method}

Both quantitative and qualitative data collection strategies were used in this study to explore the experiences of women high school principals. The quantitative investigation was designed to describe women high school principals' role conflict, role commitment, and job satisfaction as well as provide demographic information on age, ethnicity, school size, marital status, and the presence of children at home. The qualitative investigation was designed to gather data that would expand the findings of the quantitative data through in-depth interviews with women high school principals.

AU of the women who served as high school principals in public schools in Illinois, Minnesota, and Wisconsin during 1998-1999 were

Journal of School Leadership, Vol. 12, No. 1 (January 2002): pg. 57-77. Publisher Link. This article is (C Rowman \& Littlefield and permission has been granted for this version to appear in e-Publications@Marquette. Rowman \& Littlefield does not grant permission for this article to be further copied/distributed or hosted elsewhere without the express permission from Rowman \& Littlefield. 
asked to participate in this study by completing the survey instrument. The names of the women high school principals were obtained from the Wisconsin Department of Public Instruction, the Minnesota Association of Secondary School Principals, and the Illinois State Board of Education. The high school principals included those who served in traditional high schools, with grades 9 through 12, as well as secondary schools with grades 7 through 12 .

Surveys containing questions on personal and professional backgrounds along with three established questionnaires on role conflict, role commitment, and job satisfaction were mailed to all of the women identified as high school principals in Illinois, Minnesota, and Wisconsin ( $n:::$ :237). Several steps were taken to ensure a positive response to the survey. The survey instrument was limited to four pages and the packet included a note of appreciation, with a Susan B. Anthony coin attached. Of the 237 survey packets mailed, 164 were returned for a return rate of $69.2 \%$. The women high school principals were motivated to share their experiences and also indicated they were appreciative of the coin.

Three survey instruments were used for the quantitative phase of the study: a Role Conflict Questionnaire, a Role Commitment Question, and a Job Satisfaction Survey. These instruments were previously tested on samples of working women in a variety of careers. The Role Conflict Questionnaire (Nevill \& Damico, 1974) is a nine-item scale used to delineate areas of role conflict. Higher scores in this instrument indicate a greater level of role conflict. This instrument has been used to study the well-being of working women (Napholz, 1995a; Riesch, 1981). Cronbach alphas for these studies ranged from.70 to .73 .

The Role Commitment Question (Napholz, 1995b) is a one-item measure developed to subjectively identify how working women set priorities for work and relationships. Napholz offered three discrete choices to her respondents: (1) significant relationships first, (2) work equals relationship, and (3) work first. Napholz examined the association of role commitment with role conflict in her study of 106 working women and found significant differences in role commitment between the groups $(F(3,102)=5.96, p<.05)$. In the survey 
instrument used for this study an item was modified and women were asked to identify their priorities for work or significant relationships by selecting the value on a 7-point Likert scale with (1) work first and (7) significant relationships first.

The Job Satisfaction Survey (Mendenhall, 1977, revised by Schneider, 1984) is a 27-item questionnaire that was tested and used to study the job satisfaction of educators. For purposes of this study, modifications were made to the text of five items to make them appropriate for high school principals. Participants used a 4-point Likert scale for their responses with the higher numbers indicating more job satisfaction. Rice and Schneider (1994) reported the overall scale reliability to be .90 .

The participants for the qualitative phase of the study were selected from women high school principals in Wisconsin who had responded to the survey $(n=35)$. The qualitative study was limited to Wisconsin because of travel and time constraints. The sample of Wisconsin respondents was stratified into four groups based on the median scores on the role conflict and job satisfaction questionnaires. The categories were (1) below median role conflict/above median job satisfaction, (2) below median role conflict/below median job satisfaction, (3) above median role conflict/above median job satisfaction, and (4) above median role conflict/below median job satisfaction. Two participants were selected from each group, with consideration given not only to their role conflict and job satisfaction scores, but also to the designation of their high schools as urban or nonurban. This selection process was designed to allow for a diversity of experiences regarding both role conflict and job satisfaction as well as variety in the location of the high schools. However, the sample and the homogeneity of responses to job satisfaction and role conflict resulted in the scores of the respondents being quite close to the median score on both role conflict and job satisfaction.

Eight women were selected as participants for the qualitative phase of this study using the categories described above. The women agreed to participate in intensive open-ended interviews that were specifically structured to allow them to expand on their perspectives about role conflict, role commitment, and job satisfaction that had 
been presented in the survey. The participants were asked questions on how they balanced their personal and professional lives, the conflicts they experienced in their roles as high school principals, the factors that led to job satisfaction, and how they handled commitments to their families and careers.

Data for the quantitative investigation were analyzed using the Statistical Package for the Social Sciences (SPSS, Inc., 2000). Transcriptions of the interviews and field notes were entered into the NVivo ${ }^{\circledR}$ software package to facilitate the analysis of the qualitative investigation. The qualitative data were coded and themes were identified.

\section{Findings}

Findings for this study are presented in two parts. First, the personal and professional characteristics of the women high school principals are described, followed by the findings related to role conflict, role commitment, and job satisfaction. Role conflict, role commitment, and job satisfaction are then described in terms of their interactions.

\section{Personal and Professional Characteristics}

The women high school principals from the three states shared similar personal attributes. The majority identified themselves as white $(90.5 \%)$, married $(67.90 ; 6)$, and having children $(74 \%)$. The ages of the respondents ranged from 28 to 65 with a mean age of 47.71 (SD $=7.79)$. Of those respondents who had children en $=120), 58.3 \%$ had children still living at home. A comparison by state of the demographic characteristics of the respondents is found in Table 2 . There were no statistically significant differences with regard to marital status, ethnicity, parenthood, age, and age at first principalship between the three states.

Respondents had worked as teachers for an average of 13.11 years $(S D=6.7)$ prior to their first administrative positions. The mean age fm: obtaining a first high school principalship was 42.1 years ( $S D$ $=6.88$ ), with a range front 24 to 57 years. The mean number of years 
that the respondents had befell in their present high school position was 4.8 years $(S D=3.0)$.

The eight women who agreed to participate in the qualitative investigation had personal characters similar to the total survey sample. Seven were European American; one was African American. Their ages ranged from 43 to 53 years with a mean age of 40.5 years. Seven were married and had children; one was single and had never been married. Of the seven women with children, four of them had children living at home. They also reflected the total sample in terms of their ages at their first principalship, the number of years spent prior to teaching, and the number of years in their present position.

Previous research has found that women tend to be older when they obtain their first principalship than are men at their first principalship (Ortiz, 1982; Paddock, 1981; Schneider, 1986; Shakeshaft, 1989). These earlier findings are consistent with the findings of this study. The women interviewed described their ages at their first principalship not only in terms of being older than their male counterparts, but also in terms of nearing the end of their careers. Six of the eight interviewees mentioned that they had become high school principals within 5 to 8 years of their possible retirement. One of the participants, who was 52 at the time of the interview, noted, "1 wanted to commit 3 to 5 years to this school and after that we'll see. It may be time for retirement."

The late entrance of women into the principalship, coming so close to retirement age, impacts on the number of experienced women high school principals who are available for recruitment to the superintendency. Participants were asked about their career aspirations in both the surveys and the interviews. Over half of the survey respondents (58\%) indicated that they were not. interested in becoming superintendents. Only $32 \%$ of the survey respondents indicated they would consider the superintendency, while $10 \%$ did not answer at responded with "maybe." When specifically asked about their future aspirations, six of the interviewed pal1.icipants mentioned their possible retirements. One participant commented, "I don't know. I know what I want to do when I retire in terms of lily next life, and I'm probably about five years away from that," Another participant

Journal of School Leadership, Vol. 12, No. 1 (January 2002): pg. 57-77. Publisher Link. This article is (C Rowman \& Littlefield and permission has been granted for this version to appear in e-Publications@Marquette. Rowman \& Littlefield does not grant permission for this article to be further copied/distributed or hosted elsewhere without the express permission from Rowman \& Littlefield. 
commented that the longer she studied the superintendent's role, the less certain she had become about seeking that position. "It (the superintendency) strikes me as so much hand-holding with the board, I don't know if that's me. I'm terribly hands on and I really do value my relationships with people."

Some researchers have found that women educators are at a disadvantage in pursuing administrative positions because they lack mobility (Grady \& O'Connel, 1993; Paddock, 1981; Schneider, 1986). This was not necessarily the case for the women high school principals in this study. They were to move and, indeed, had moved to accept positions as high school principals. Thirty-sex percent of the respondents expressed a willingness to move to another community within their own state, while $17 \%$ were willing to move within their state or, if necessary, outside their state to obtain a principal ship. Forty-seven percent of the survey respondents were not willing to move beyond their community for a position as a high school principal. The experiences of the women who participated in the interviews also demonstrate that women perceive that they have some mobility. Four of the eight participants interviewed had moved to new communities within Wisconsin in order to become high school principals, and one participant had moved from another state for her position. Only three of the interviewees had become high school principals in the same distract where they were already employed.

The findings of the qualitative investigation were consistent with previous research that noted the importance of mentors who provided support, encouragement, and networking opportunities in furthering women's careers in educational administration (Conh, 1989; Grogan, 1996; Mertz, 1987). In particular, women in educational administration were found to have benefited from having women as their mentors because female mentors could better explain the unwritten rules of the organization and identify the informal networks (Fleming, 1991; Hill \& Ragland, 1995). Seven of the eight participants interviewed in this study mentioned that mentors had helped them in their careers. Five of the interviewees indicated that it had been female educational administrators who had encouraged them to apply for administrative positions and to enroll in administrative certification programs. One participant reported, "I would never have gotten 
through these years, except that at every single turn, she said, 'You stick to your guns. You're doing the right thing! And you're going to make it."'

Some previous research has argued that women tend not to provide mentorship to other women (McKenna, 1997; Schneider, 1986). However, four of the women in this study were actively mentoring other women for positions in educational administration. They felt it was their responsibility to encourage women to enter educational administration. One participant clearly stated her view of the importance of mentoring other women: "I feel that it's important to mentor women I work with who might, with some encouragement, be interested [in the high school principalship]."

The interviewees were also well aware of the positions as role models for female students and teachers. As one participant noted, "That's why I think it's good for our kids that someone like myself is here, so they can see that women can do a variety of things." Another participant commented: "I am proud of being a high school principal. I'm very aware when I walk down the halls of being a role model for the girls."

Several studies have reported on the importance of encouragement from university professors, family members, and training programs in the development of career aspirations for women educators (Gotwalt, 1986; Grady, 1992; Grady, Carlson, \& Brock, 1992). Though all the participants interviewed had been involved in programs in educational administration, either for their master's degrees or for administrative certification, they had received inconsistent levels of support from their professors. One woman commented that there had been no direct encouragement from faculty in her educational administration programs. "I don't believe that any professors actually came up to me and said, 'Oh, you should be doing this.' If you were in the program, you were in it." Another interviewee was critical of the materials in her educational administration courses. Looking back, she commented, "as I read through it, the authors kept talking about men, men, men and I didn't fit in the style that men used, and as I read it, I felt incompetent." Only one of the interviewees reported receiving direct encouragement from her 
NOT THE PUBLISHED VERSION; this is the author's final, peer-reviewed manuscript. The published version may be accessed by following the link in the citation at the bottom of the page.

professors in terms of teaching assistantships and help in job searches.

\section{Role Responsibilities and Role Balance}

Survey respondents indicated on average a moderate degree of role conflict, 3.83 ( $S D=1.11$ ), with a range of .88 (low role conflict) to 6.60 (very high role conflict). The Cronbach alpha for the Role Conflict Questionnaire for this study was .76. The Role Conflict Questionnaire asked respondents to rate the degree of conflict they experienced based on their expectations for themselves, time management, household management, feelings of guilt, expectations of others, financial matters, relations with husband, and child care concerns. Nevill and Damico (1974) found the highest areas of role conflict were those areas that involved a woman's feelings of self and her ability to successfully manage her time. The women principals interviewed for this study expressed concerns about themselves in terms of their capabilities to perform as principals and their expectations for themselves. One of the interviewees commented: "Probably the biggest thing that I've struggled with is my head. Am I capable? Can I do this?" Another woman noted that it was only after eight years that she recognized that she was smart enough and had the energy for the work. A third principal described role conflict for her as the "inner conflict" caused by "my own expectations of what I want to be as a wife and a mother." She felt that the affirmations she received as a high school principal did not "outweigh my internal struggle to be a better mom and wife."

The incredible time demands that were faced by the women in their positions as high school principals was a theme that emerged from the interviews. One of the interviewees commented: "There is never a week I work less than 70 hours. It is a minimum of a 12-hour day, and it is another 8 hours on the weekends." Another participant noted that she worked "Two, three nights a week, 60-hour workweeks." All of the interviewed participants, regardless of the size of their high schools, experienced conflicts over time demands.

Interviewed participants who had children at home expressed a high level of role conflict. One of the interviewees who no longer had

Journal of School Leadership, Vol. 12, No. 1 (January 2002): pg. 57-77. Publisher Link. This article is (C Rowman \& Littlefield and permission has been granted for this version to appear in e-Publications@Marquette. Rowman \& Littlefield does not grant permission for this article to be further copied/distributed or hosted elsewhere without the express permission from Rowman \& Littlefield. 
young children described the role conflict generated by children when she stated, "I go to work all the time and any time. If I had younger children of any age that really needed me, it never could have happened." Other participants described the extremely long hours that included evening and weekend work that kept them from their children. Several of the interviewees commented on how difficult it is to "do all of the juggling between the family and job." As one interviewee commented: "No matter how much we say our husbands are helpful, mom is usually the nurturer and the caregiver and the worrywart. You know, you're the organizational person. I mean, it's stressful!" Another women noted that the stress and the demands of the principalship had resulted in her health failing:

My health has not been as good as I want to be. I've gained weight in the three years that I've had this position. I stopped exercising because I don't have time to do it. I get more colds and flu. If I had to do this for a long, long time, I think that it would definitely have a more dentrimental effect on my health.

In order to measure role commitment, the respondents were asked to place themselves on a 7-point continuum from work first (1) to significant relationships first (7). The group as a whole scored on average $4.54(S D=1.74)$. This indicates that women high school principals were attempting to balance work and relationships nearly equally. Napholz (1995b) found that the women in her study who tried balance work and relationships equally experienced more role conflict than did those who chose either work or significant relationships first.

The interviewed participants articulated clearly their personal struggles in choosing between work and family. One interviewee commented:

I like to work and I like to get things done... I guess I'm learning to let work not slide, but take a backset to some personal kinds of things. It's hard to do because I feel commitment to both, a tremendous commitment.

Another participant selected family first and commented, "As a parent you're constantly torn between the job and your family. So, how do you balance that? Work your way through it the best you can. 
To me, family is the most important thing." One interviewee had resolved the struggle by dividing up the week

I'd say Monday through Friday, it's work first. On Saturday, it's family first. On Sunday, it's half-and-half. I'm able to do that because I'm at an age where I have an empty nest so I think that allows me some leeway. Until my child was a junior in high school, family came first.

The comments of some of the interviewees indicate the complex nature of role commitment. They reported that there was a relationship between their tenure as a high school principal and their role commitment. The women who had been principals for over five years felt that the longer they served as principals, the more they knew what was important in their lives and the easier it became to choose family and friends over work. When they had first become high school principals they felt that they had to prove themselves and consequently would choose work first. Paradoxically, those women who had become high school principals later in their lives, when their children were not as time consuming, had found it much easier to commit to their work first.

\section{Job Satisfaction}

The survey respondents were moderately satisfied with their jobs. The scores on the Job Satisfaction Questionnaire ranged from 1.93 (dissatisfied) to 3.96 (very satisfied) on the 4-point Likert scale with an average of $2.84(S D=.39)$. The Cronbach alpha for the Job Satisfaction Questionnaire for this study was .90. The level of satisfaction with other administrators and coworkers, opportunities for growth and career advancement, school characteristics, financial aspects, conditions of the plant and facilities, amount of work, administrator-student ratio, pupil-administrator relations, and community relations were measured by this questionnaire.

The participants in the interviews were generally satisfied with their positions as high school principals. When asked about job satisfaction, one participant commented: "I consider this a fantastic job. I like every facet of it. Nobody really talked about how much fun it 
is, because I think it can be." Another participant stated: "I guess I really like my job and I'm glad that I took this job. I think it's a good job. I really do." The interviewees reported that their job satisfaction was affected by (1) their length of time in the principalship, (2) their work with teachers, (3) the bureaucracy and politics of the school district, and (4) their interactions with students. They felt that the longer they served as a high school principal, the more their satisfaction with the position increased. One interviewee reported that in her third year in her position she had begun "feeling more comfortable with the role. I've got a little better handle on what's going on and how to anticipate things I feel a little more on top of things and therefore a little more confident." Another participant, who was in her eighth year as a high school principal, felt she was "not getting into as many struggles."

The interviewees mentioned that working with teachers was both a very satisfying aspect of their jobs as well as an aspect that could cause dissatisfaction. As one interviewee explained, "I derive a lot of satisfaction in my relationships with my teachers...seeing them happy, successful, growing, using new instructional techniques, trying strategies, and then becoming leaders themselves." On the other hand, teachers also cause dissatisfaction because

no matter how many different ways you've tried to work with that teacher to get them to be more effective with kids or to deal better with parents or to be a nice person to their teammates...it's still the same old, same old...and it still gets to me.

The level of dissatisfaction with their jobs was also related to the bureaucracy and politics of the school district. The amount of paperwork and the lack of autonomy and depth in the district frustrated the interviewees. They disliked "central office micromanaging." In particular one interviewee mentioned that a major source of dissatisfaction was "lots of daily and weekly faxes from central administration. Being pulled from central administration and at the same time trying to get your job done here."

A major source of satisfaction mentioned by all the participants was the interactions they had with their students. One interviewee explained this source of job satisfaction:

Journal of School Leadership, Vol. 12, No. 1 (January 2002): pg. 57-77. Publisher Link. This article is (C Rowman \& Littlefield and permission has been granted for this version to appear in e-Publications@Marquette. Rowman \& Littlefield does not grant permission for this article to be further copied/distributed or hosted elsewhere without the express permission from Rowman \& Littlefield. 
I really enjoy watching kids succeed...My very best day of the year is graduation. It's not because it's over. No, No! It's because it's so nice to watch every kid personally walk across the stage."

The relationship between role conflict and job satisfaction was apparent in both the survey results and the interviews. Role conflict was inversely and significantly related to job satisfaction $(r=-.366, p$ $=.01)$. The more role conflict, the lower the level of job satisfaction. The women who participated in the interviews describe time demands as a major source of their role conflict. When time demands become too onerous, participants in the interviews explain that they become less satisfied with their jobs and they attempt to set clearer parameters for their time. They tell their teachers, parents, and students that they will not attend every extracurricular event. One of the participants worried that this approach might not be well received by all her of her constituents, but she felt that her need for balance in her life was worth the risk.

The women in the study were principals of high schools ranging in size from 26 to 3,115 students, with $35 \%$ of the high schools having over 900 students. The participants interviewed reported that the size of the high school, in terms of the number of students enrolled, impacted both job satisfaction and role conflict. Three of the participants interviewed felt that high schools with more than 1,500 students were less satisfying places to work. One participant, whose high school had 1,120 students, felt that

any high school that is over a thousand and we're pushing it...It's much more difficult to manage, just because it's that much bigger. You approach 1,500, 1,800, 2,000 and you're dealing with a whole different place than you are in a thousand. You don't get to know people. You don't get to know faces. It's a bad place, in my opinion, for both the adults and the kids in that building.

Another participant observed,

With a smaller high school, you certainly feel as if you can get more things done-you can have a greater impact. You can be more of an instructional leader than a

Journal of School Leadership, Vol. 12, No. 1 (January 2002): pg. 57-77. Publisher Link. This article is (C) Rowman \& Littlefield and permission has been granted for this version to appear in e-Publications@Marquette. Rowman \& Littlefield does not grant permission for this article to be further copied/distributed or hosted elsewhere without the express permission from Rowman \& Littlefield. 
manager. When the schools gets too big, the principals ends up just being a manager.

Participants noted that there was more role conflict with a larger school because "you would have more conflicts that bite into your own personal time. You have more help in terms of supervisors, but there will be certain times when you have to be there." However, one participant felt that a smaller high school would cause more role conflict for the principal because there would be fewer resources and limited organizational help. "You still have to do all the organizational things...You'd have fewer people working with you. You have to wear more hats." She felt that her school, with around 800 students, was ideal because she was able to get to know and work with students and teachers.

\section{Conclusions}

The disproportionately low representation of women in the public high school principalship was demonstrated in this study with data that indicated that women held only $15.2 \%$ of the high school principals in Illinois, Minnesota, Wisconsin where $48.5 \%$ of the secondary school teachers were women. The policies and laws advocated by feminists in the 1970s and 1980s, such as affirmative action, the Equal Rights Amendment, and Title IX, have clearly had an insignificant impact on increasing the number of women in the high school principalship (Stromquist, 1997). Feminist researchers who articulate "power and politics" theories would not find the persistent underrepresentation of women in administrative positions surprising. They have argued that legislation and court rulings were merely the actions of a government that "essentially supports the social relations of male dominance in society" (Stromquist, 1997, p. 68). Women are relying on men in positions of power, such as the superintendency, to share their power by creating more access for women to the male power base (Marshall, 1999; Marshall \& Anderson, 1995).

Recent research has indicated a growing shortage of qualified candidates for the position of high school principal (Olson, 1999; Protheroe, 2001). The pool of candidates for principalship would be increased if more women could be attracted to the position. The 
information gained in this study suggests that consideration must be given to the role of the principal in terms of role conflict, role commitment, and job satisfaction in order for school districts to attract and retain women in the high school principalship. Findings in the study demonstrate that changes will have to be made to the expectations for the high school principal to make the position more attractive. Similarly, Merrill and Pounder (1999) challenged district supervisors to "explore ways to improve the daily work life and job satisfaction of each principal through such things as stress reduction, workload management and pecuniary incentives" (p. 46).

One of the expectations of the high school principalship that should be closely examined is the extensive time demand, in terms of extracurricular activities and evening and weekend meetings. The findings of this study indicate that the onerous time demands placed on the high school principal cause role conflicts for women who continue to be faced with balancing family responsibilities with the responsibilities of their jobs. Participants in the study struggled to balance their personal and professional lives. Those women high school principals who tried to balance equally their commitment to work and family expressed greater role conflict and less job satisfaction. Female teachers who may aspire to the high school principalship assume that only "superwomen" can balance the role conflicts of the high school principalship because there are so few women in that position (Schmidt, 1992).

Role conflict also influences the career choices and decision making of female educators regarding their pursuit of the high school principalship. Women educators often do not know that considering the high school principalship later in their careers is not an uncommon occurrence for women. The interviewed participants had delayed their entrance into "high powered, time-consuming" positions like the high school principalship until their children were grown so that they could reduce the conflicts between their careers and their family roles. For many of the participants this is the reason why they did not become principals until they were older. However, entering the position of principalship later in their lives may alter future career paths. When asked about their aspirations, the participants discussed being within five years of retirement, rather than considering a career path that 
may have led to positions such as assistant superintendent or superintendent. To attract women to the high school principalship earlier in their careers will require an understanding by school boards, district administrators, and the high school community of the multiple demands and expectations that mark the lives of women.

The women high school principals in this study described their work with students and teachers as sources of job satisfaction. These are the very elements of the high school principalship that should be highlighted in order to attract more women educators to the position. Job satisfaction in the high school principalship is also related to the number of students in the high school. Data in the quantitative investigation indicated that job satisfaction increased as the size of the school increased. Qualitative interview data, however, indicated that schools that were too small or too large contributed to job dissatisfaction and role conflict. Interviewees were most satisfied with high schools with between 800 and 1,500 students. It would be valuable to further explore the relationship between job satisfaction and the number of students in a school to ascertain what size high school provides the most job satisfaction for both female and male principals.

Women have long been assumed to be less mobile in terms of their career choices than men and, thus, limited in the high school principalship positions they could pursue. Findings from this study indicate that women today may be more willing to move to accept positions that enhance their careers than was true in the past. The question of mobility should be more thoroughly investigated in terms of its impact on career choices for women and men.

The representation of women in the high school principalship may increased if there is an effort made to recruit, encourage, and mentor women considering educational administration. This study illustrates that female teachers who exhibit a potential or express a desire for administration should be identified by other administrators and offered leadership opportunities. Mentoring was a key factor in enabling women in this study to become high school principals. Professors in educational administration programs can also play a role in increasing the number of women educators who consider the high 
school principalship by serving as mentors and by providing course readings that address the concerns of women in educational administration.

There is a continued need for research that focuses exclusively on the high school principalship from a woman's perspective. The information available on the experiences and challenges facing women who are high school principals needs to be expanded. Studies that compare female and male high school principals in terms of role conflict, role commitment, and job satisfaction are also needed to develop a broader understanding of the high school principalship. Perhaps in today's society, with a large number of two-career families, the role conflicts experienced by male and female high school principals will be similar. An understanding of similarities and differences in the perceptions held by men and women high school principals about role conflict, role commitment, and job satisfaction could contribute to the development of a more realistic set of expectations for the high school principal.

In the meantime, school administrators, school boards, and professors of educational administration must be mindful that women educators consider role conflicts, role commitment, and job satisfaction when making decisions regarding the desirability of the high school principalship. To increase the number of women in the high school principalship attention must be paid to the impact of these constructs. Having more women high school principals will demonstrate to teachers and students alike that educational administration is a career choice that is available for both women and men. The high school need not continue to be a place where women teach and men lead.

\section{References}

Alley, R., \& MacDonald, S. (1997, March). Using gender knowledge to prepare for secondary school leadership as a principal. Paper presented at the annual meeting of the American Educational Research Association, Chicago. (ERIC Document Reproduction Service No. ED 408 695)

Bacharach, S., \& Mitchell, S. (1983). The sources of dissatisfaction in educational administration: A role-specific analysis. Educational Administration Quarterly, 19(1), 101-128. 
NOT THE PUBLISHED VERSION; this is the author's final, peer-reviewed manuscript. The published version may be

accessed by following the link in the citation at the bottom of the page.

Bell, C., \& Chase, S. (1993). The underrepresentation of women in school leadership. In C. Marshall (Ed.), The new politics of race and gender. Washington, DC: Falmer Press.

Blount, J. (1998): Destined to rule the schools: Women and the superintendency, 1873-1995. Albany, NY: State University of New York Press.

Bogotch, I., \& Riedlinger, B. (1993). A comparative study of new and experienced principals within an urban school system. Journal of School Leadership, 3, 484-497.

Brunner, C, C. (1997, Fall). Women's ways of succeeding in educational administration. ERS Spectrum, 25-31.

Cochran, J. (1979). How do women administrators view job satisfaction and discrimination? In M. Berry (Ed.), Women in educational administration: A book of readings (pp. 150-152). Washington DC: National Association for Women Deans, Administrators and Counselors.

Cohn, K. (1989, November). Factors associated with the involuntary reassignment of three women principals. Paper presented at the annual conference of Research on Women and Education, San Diego. (ERIC Document Reproduction Service No. ED 314 831)

Edson, S. (1988). Pushing the limits: The female administrative aspirant. Albany. NY: State University of New York Press.

Erickson, L. (1985, December). Conflict and the female principal. Phi Delta Kappan, December, 1985, 288-291.

Fansher, T., \& Buxton, T. (1984). A job satisfaction profile of the female secondary school principal in the United States. National Association of Secondary School Principals Bulletin, 68(468), 32-39.

Fleming, K. (1991). Mentoring: Is it key to opening doors for women in educational administration? Education Canada, 31(3), 27-33.

Goeller, K. (1995, November). Principal leadership: The female component. National Association of Secondary School Principals Bulletin, 105-116.

Gotwalt, N., \& Towns, K. (1986). Rare as they are, women at the top can teach us all. The Executive Educator, 13-15.

Grady, M. (1992). Women and educational administration: Certified but not employed. Educational Considerations, 20(1), 33-36.

Grady, M., Carlson, K., \& Brock, B. (1992). School administrators: The next generation. Journal of School Leadership, 2, 443-455.

Grady, M., \& O'Connell, P. (1993). Women in K-12 educational administration: A synthesis of dissertation research. Journal of School Leadership, 3, 449-460.

Grogan, M. (1996). Voices of women aspiring to the superintendency. Albany, NY: State University of New York Press.

Journal of School Leadership, Vol. 12, No. 1 (January 2002): pg. 57-77. Publisher Link. This article is (C Rowman \& Littlefield and permission has been granted for this version to appear in e-Publications@Marquette. Rowman \& Littlefield does not grant permission for this article to be further copied/distributed or hosted elsewhere without the express permission from Rowman \& Littlefield. 
NOT THE PUBLISHED VERSION; this is the author's final, peer-reviewed manuscript. The published version may be accessed by following the link in the citation at the bottom of the page.

Gunn, J., \& Holdaway, E. (1986). Perceptions of effectiveness, influence, and satisfaction of senior high school principals. Educational Administration Quarterly 22(2), 43-62.

Hill, M., \& Ragland, J. (1995). Women as educational leaders: Opening windows, pushing ceilings. Thousand Oaks, CA: Corwin Press.

Hochschild, A (1989). The second shift: Working parents and the revolution at home. New York: Viking Press.

Kelly, R. M. (1997). Gender culture and socialization. In D. Dunn (Ed.), Workplace/women's place: An anthology. Los Angeles: Roxbury Publishing.

Kochan, F., Spencer, W., \& Mathews, J. (2000). Gender-based perceptions of the challenges, changes; and essential skills of the principalship. Journal of School Leadership, 10, 290-310.

Marshall, C. (1999). Researching the margins: Feminist critical policy analysis. Educational Policy, 13(1), 59-77.

Marshall, C., \& Anderson, G. (1995). Rethinking the public and private spheres: Feminist and cultural studies perspectives on the politics of education. In J. Scribner and D. Layton (Eds.), The study of educational politics (pp. 169-182), London: FaImer Press.

Marshall, C., \& Kasten, K (1994). The administrative career: A casebook on entry, equity, and endurance. Thousand Oaks, CA: Corwin Press.

Matthews, E. (1995). Women in educational administration: Views of equity. In D. Dunlap \& P. Schmuck (Eds.), Women leading in education (pp. 247-273). New York: State University of New York Press.

McCarthy, M., \& Zent, A. (1981, Fall). School administrators: 1980 profile. Planning and Changing, 145-161.

McKenna, E. P. (1997). When work doesn't work anymore. New York: Dell Publishing.

Mendenhall, D. R. (1977). Relationship of organizational struct.ure and leadership behavior to teacher job satisfaction in IGE schools. (Tech. Rep. No. 412). Madison, WI: Wisconsin Research and Development Center for Cognitive Learning.

Merrill, R., \& Pounder, D. (1999, November). Attraction and retention of high school principals. Paper presented at the annual meeting of the University Council for Educational Administration, Minneapolis, MN.

Mertz, N. (1987). Why women aren't mentored. Paper presented at the American Educational Research Association Annual Meeting, Portland, Oregon.

Mertz, N. (1991). Females in school administration: Making sense of the numbers, Planning and Changing, 22(1), 34-35.

Mertz, N., \& McNeely, S. (1988). What's happening to school administration: Gender in line administration. Planning and Changing, 19(3), 166-177.

Journal of School Leadership, Vol. 12, No. 1 (January 2002): pg. 57-77. Publisher Link. This article is (C Rowman \& Littlefield and permission has been granted for this version to appear in e-Publications@Marquette. Rowman \& Littlefield does not grant permission for this article to be further copied/distributed or hosted elsewhere without the express permission from Rowman \& Littlefield. 
NOT THE PUBLISHED VERSION; this is the author's final, peer-reviewed manuscript. The published version may be accessed by following the link in the citation at the bottom of the page.

Mertz, N., \& McNeely, S. (1990, April). Groundbreakers: Females who "succeed" in male-dominated line administrative positions. Paper presented at the American Educational Research Association annual meeting, Boston.

Mertz, N., \& McNeely, S. (1994). How are we doing? Women in urban school administration. Urban Education, 28(4), 361-371.

Napholz, L. (1995a). Mental health and American Indian women's multiple roles. American Indian and Alaska Native Mental Health Research: Journal of the National Center, 6(2), 57-75.

Napholz, L. (1995b). Indexes of psychological well-being and role commitment among working women. Journal of Employment Counseling 32(1), 22-32.

Nevill, D., \& Damico, S. (1974). Development of a role conflict questionnaire for women: Some preliminary findings. Journal of Consulting and Clinical Psychology, 42(5), 743.

Nogay, K, \& Beebe, R. (1997). Gender and perceptions: Females as secondary principals. Journal of School Leadership 7, 246-265.

Olson, L. (1999, March 3). Demand for principals growing, but candidates aren't applying. Education Week, 18(25), 1, 20, 22.

Ortiz, F. (1982). Career patterns in education: Women, men and mi1w1'ities in public school administration. New York: Praeger.

Paddock, S. (1981). Male and female career paths in school administration. In P. Schmuck, W. Charters, \& R. Carlson (Eds.), Educational policy and management: Sex differentials (pp. 187-198). New York: Academic Press.

Pavan, B. (1991, April). Reflections of female school administrators regarding their careers. Paper presented at the annual meeting of the American Educational Research Association, Chicago. (ERIC Document Reproduction Service No. ED 334 676)

Pavan, B. (1999). The first years: What should a female superintendent know beforehand? In C. Brunner (Eel), Sacred dreams: Women and the superintendency (pp. 105-123). New York: State University of New York Press.

Pigford, A, \& Tonnsen, S. (1993). Barriers to the good ol' boy network. In A Pigford \& S. Tonnsen (Eds.), Women in school leadership (pp. 7-18). Lancaster, PA: Technomic Press.

Porat, K. (1985). The woman in the principal's chair in Canada. Phi Delta Kappan, 67(4), 297-301.

Pounder, D. (1900, October). Educational megatrends and increased female leadership in schools. Paper presented at the annual meeting of the University Council for Educational Administration, Pittsburgh.

Journal of School Leadership, Vol. 12, No. 1 (January 2002): pg. 57-77. Publisher Link. This article is (C Rowman \& Littlefield and permission has been granted for this version to appear in e-Publications@Marquette. Rowman \& Littlefield does not grant permission for this article to be further copied/distributed or hosted elsewhere without the express permission from Rowman \& Littlefield. 
NOT THE PUBLISHED VERSION; this is the author's final, peer-reviewed manuscript. The published version may be accessed by following the link in the citation at the bottom of the page.

Pounder, D. (1994). Educational and demographic trends: Implications for women's representation in school leadership. In N. A Prestine \& P. W Thurston (Eds.), Advances in Educational Administration 3, 135-149.

Protheroe, N. (2001, April). Attracting and retaining high-quality people for the principalship: Problems and possibilities. Paper presented at the annual meeting of the American Educational Research Association, Seattle.

Rice, E. M., \& Schneider, G. T. (1994). A decade of teacher empowerment: An empirical analysis of teacher involvement in decision making, 19801991. Journal of Educational Administration, 32(1), 43-58.

Riesch, S. (1981). Occupational commitment, role conflict, and the quality of maternal-infant interaction. Unpublished doctoral dissertation, Rush University, Chicago, IL.

Rogus, J., Poppenhagen, B., \& Mingus, J. (1980). As secondary principals view themselves: Implications for principal preparation. High School Journal 63(4), 167-172.

Scherr, M. (1995). The glass ceiling reconsidered: Views from below. In D. Dunlap \& P. Schmuck (Eds.), Women leading in education (pp. 313326). New York: State University of New York Press.

Schmidt, L. (1992, September). Women in educational administration-A disappearing construct. Paper presented at the annual conference of Women in Administration, Lincoln, NE. (ERIC Document Reproduction Service No. ED 350707).

Schmuck, P. (1981). The sex dimension of school organization: Overview and synthesis. In P. Schmuck, W. Charters, \& R. Carlson (Eds.), Educational policy and management: Sex differentials (pp. 221-234). New York: Academic Press.

Schmuck, P., \& Schubert, J. (1995). Women principals' views on sex equity: Exploring issues of integration and information. In D. Dunlap \& P. Schmuck (Eds.), Women leading in education (pp. 274-287). New York: State University of New York Press.

Schneider, G. T. (1984). Teacher involvement in decision making: Zones of acceptance, decision conditions, and job satisfaction. Journal of Research and Development in Education, 18(1), 25-32.

Schneider, G. T. (1986, April). Career path and mobility differences of women and men in educational administration. Paper presented at American Educational Research Association, San Diego, CA

Shakeshaft, C. (1989). Women in educational administration. Newbury Park, CA; Corwin Press.

Stromquist, N. (1997). Gender policies in American education. In C. Marshall (Ed.), Feminist critical policy analysis I: A perspective from primary and secondary schooling (pp. 54-72). London: Falmer Press.

Journal of School Leadership, Vol. 12, No. 1 (January 2002): pg. 57-77. Publisher Link. This article is (C Rowman \& Littlefield and permission has been granted for this version to appear in e-Publications@Marquette. Rowman \& Littlefield does not grant permission for this article to be further copied/distributed or hosted elsewhere without the express permission from Rowman \& Littlefield. 
NOT THE PUBLISHED VERSION; this is the author's final, peer-reviewed manuscript. The published version may be accessed by following the link in the citation at the bottom of the page.

Valentine, P. (1995). Wornell's working worlds: A case study of a female organization. In D. Dunlap \& P. Schmuck (Eds.), Women leading in education (pp. 340-357). New York: State University of New York Press.

\section{Appendix}

Table 1: A Comparison of Women High School Principals and Teachers by State

\begin{tabular}{lccc}
\hline & $\begin{array}{c}\text { Number of High } \\
\text { School Principals }\end{array}$ & $\begin{array}{c}\text { Percent of Female } \\
\text { High School Principals }\end{array}$ & $\begin{array}{c}\text { Percent of Female } \\
\text { High School Teachers }\end{array}$ \\
\hline Illinois & 673 & 18.3 & 49.2 \\
Minnesota & 422 & 17.1 & 47.6 \\
Wisconsin & 458 & 9.2 & 48.7 \\
Total & 1.553 & 15.2 & 48.5 \\
\hline
\end{tabular}

Table 2: Demographics of Women High School Principals

\begin{tabular}{|c|c|c|c|c|}
\hline & $\begin{array}{c}\text { Illinois } \\
\text { (percent) } \\
n=74\end{array}$ & $\begin{array}{c}\text { Minnesota } \\
\text { (percent) } \\
n=49\end{array}$ & $\begin{array}{c}\text { Wisconsin } \\
\text { (percent) } \\
n=34\end{array}$ & $\mathrm{x}^{2} p$ \\
\hline Married & 65.3 & 731 & 65.7 & $94, p=62$ \\
\hline White & 87.8 & 94.0 & 91.2 & 1.34, $p=51$ \\
\hline \multirow[t]{2}{*}{ Have Children } & 73.3 & 80.8 & 77.1 & $95, p=.62$ \\
\hline & $\underset{(S D)}{M}$ & $\frac{\mathrm{M}}{(S D)}$ & $\frac{M}{(S D)}$ & F. $p$ \\
\hline Age & $\begin{array}{l}47.51 \\
(7.70)\end{array}$ & $\begin{array}{l}47.92 \\
(8.25)\end{array}$ & $\begin{array}{l}47.85 \\
(7.51)\end{array}$ & $.05 . p=.96$ \\
\hline Age 1st Principalship & $\begin{array}{l}42.05 \\
(6.69)\end{array}$ & $\begin{array}{l}41.23 \\
(7.31)\end{array}$ & $\begin{array}{l}43.45 \\
(6.62)\end{array}$ & $1.03, p=.36$ \\
\hline
\end{tabular}

Journal of School Leadership, Vol. 12, No. 1 (January 2002): pg. 57-77. Publisher Link. This article is (C) Rowman \& Littlefield and permission has been granted for this version to appear in e-Publications@Marquette. Rowman \& Littlefield does not grant permission for this article to be further copied/distributed or hosted elsewhere without the express permission from Rowman \& Littlefield. 